\title{
Scarf osteotomy in tailor's bunion: A review
}

\author{
Marco Caforio $^{1 *}$, Pietro Maniscalco ${ }^{1}$, Patrizia Mantelli ${ }^{1}$ and Luigi Bisogno ${ }^{2}$ \\ ${ }^{1}$ Department of Orthopaedics and Traumatology, "G. da Saliceto Hospital”, Italy \\ ${ }^{2}$ Department of Orthopaedics and Traumatology, "Scarnati Clinic”, Italy
}

\begin{abstract}
Tailor's Bunion (TB) is a prominence of the Vth metatarsal bone at the base of the little toe. Scarf Osteotomy (SO) is a very useful technique to treat TB and in some cases it represents the first-rate surgical treatment for this deformity. The aim of this paper is to describe this little known pathology, analyze all surgical techniques of the past and review controlled trials or reviews that compare SO in TB published in the literature. All studies published in the literature have shown good results about the stability of the deformity correction over time, recovery of function of the little toe and pain.
\end{abstract}

\section{Introduction}

Tailor's Bunion (TB), or Bunionette, or Digitus Quintus Varus, is a prominence of the Vth metatarsal bone at the base of the little toe, as described by Davies in 1949 [1]. This prominence was firstly observed in tailors sitting when crossing their legs because of putting pressure on the outer borders of their feet. Usually, it is clinically characterized by pain and formation of the callus, and radiographically by a wide angle between the $\mathrm{IV}^{\text {th }}$ and $\mathrm{V}^{\text {th }}$ metatarsal bones, a wide metatarsophalageal angle and a deformity in varus of the metatarsophalangeal joint [2]. The conservative treatment consists in the use of comfortable shoes, but when this treatment is not possible to apply, the surgery is recommended.

The literature has shown many surgical treatments about TB [3-6], but some authors have highlighted the power of osteotomical techniques in comparing to simple exostectomies without internal fixation [7] for the increased incidence of recurrence. In a few cases of TB, procedures can be arthroplasty or silastic sphere implants [8].

Vth metatarsal osteotomies are divided into distal, proximal or shaft, such as the surgical management of hallux valgus. Since '50 years, the Vth metatarsal osteotomies with medial transposition of its distal part are very frequent: the transversal neck osteotomy [9], Mitchell's osteotomy [10], the oblique neck osteotomy [11] with the compact of osteotomized fragment on the medial cortical bone [12], the "V" sliding osteotomy in traversal plane (like Chevron) [13,14], the wedge osteotomy (like Reverdin) [15], the semicircle osteotomy with a medial convexity [16], the derotation and the transposition neck osteotomy [17], the wedge oblique osteotomy medially closed [18], the distal horizontal osteotomy [3], the S.E.R.I. (simple, effective, rapid, inexpensive) osteotomy [6], the osteotomy of the base [19] or other simple proximal, distal or diaphyseal osteotomies [20] associated with a lateral metatarso-phalangeal capsulotomy [21].

Choosing the most useful surgical technique is not easy because of several explanations, as follows: the simple lateral condilectomy with bursectomy is useful in large metatarsal heads (like Du Vrier's purpose [22]), the distal subcapital osteotomy in valgus deformities and the obliqual shaft osteotomy in "sabre-blade" proximal shaft deformities $[2]$.
Considering the large number of procedures, a single surgical technique is preferred to solve all issues of the diversity of anatomopathological forms. The main evolution of all correction techniques is represented by a shaft osteotomy: the Scarf Osteotomy [23]. It uses three cutting lines: a longitudinal (along the diaphysis), and two trasversal (anterior and posterior perpendicural at the first longitudinal cut). Thus nine osteotomized fragment displacements are possible: four on the dorsal-plantar plane (medial or lateral translation, with a medial or lateral rotation) and five on the sagittal plane (shortening, lengthening, lowering, axial rotation and elevation). It allows a triplar metatarsal correction, which is not allowed for the other techniques, and it also permits an easier fixation without involving the vascular supply.

Although Scarf Osteotomy technique was created for the first metatarsal deformities, Barouk used this technique in cases of Digitus Quintus Varus [24]. Its transverse bony cuts are performed with an angle of $30^{\circ}$ on the longitudinal cut of the big toe, and with the resultant displacement of the Vth head fragment towards the big toe: its osteotomy and its correction are in the reverse direction to the traditional Scarf Osteotomy (used for the big toe). This surgical procedure is a viable option, especially in cases of "sabre-blade" $\mathrm{V}^{\text {th }}$ metatarsal deformities.

According to this introduction and our experience, Scarf Osteotomy is the most adequate technique, and it is the first-rate treatment in cases of TB in our Orthopaedic Department, already used for the first metatarsal deformity. Thus the purpose of this study is the review of the published literature about Scarf Osteotomy in TB cases.

\section{Materials and methods}

The literature review is systematically conducted by using some

Correspondence to: Marco Caforio, MD, Department of Orthopaedics and Traumatology, "Guglielmo da Saliceto" Hospital, Via Taverna, 49, 20121 Piacenza, Italy, Tel: +39 349 4507950; Fax: +39 0523 303120; E-mail: marco.caforio@tiscali.it/m.caforio@ausl.pc.it

Received: February 25, 2015; Accepted: April 07, 2015; Published: April 10, 2015 
database (i.e. PubMed, EMBASE, CINAHL) and considering articles until November 2014. Clinical cases that report controlled trials and review comparing Scarf Osteotomy in TB are included. The quality of studies is assessed. The titles and abstracts of all articles are reviewed following study-selection criteria. Each full-text manuscript is systematically evaluated according to: the study typology, its characteristics (i.e. the deformity degree, the evaluation foot scoring system, the age of patients), the aspects of the surgery (i.e. surgeon's ability about Scarf Osteotomy Technique, the type of fixation, followups), the targeted outcomes, and the major findings.

\section{Results}

There are many studies that describe Scarf Osteotomy as a possible surgical technique in TB, but only three studies analyze its main role and have Scarf Osteotomy and Tailor's Bunion in the title. These articles are Seide and Petersen, 2001 published on Archives of Orthopaedic and Trauma Surgery [25], Maher and Kilmartin, 2010 published on Foot and Ankle International Journal [26] and Guga et al. 2012 published on Foot and Ankle Surgery Journal [27] (Table 1).

\section{Discussion}

The Scarf Osteotomy is a Z-shaped metatarsal osteotomy, which is commonly used for the correction of an increased intermetatarsal I/II angle in patients with hallux valgus [28]; its main advantage is the high primary stability [29].

The first article on the Scarf Osteotomy [25] is about TB caused by an increased angle between the $\mathrm{IV}^{\text {th }}$ and $\mathrm{V}^{\text {th }}$ metatarsal bone: in this study the authors analyze both clinical results through the Fore Foot Scoring System (FFSS), in according to Kitaoka scoore [12], and radiological results of their surgical procedure in ten symptomatic patients. They were treated between 1997 and 1998 with the osteotomy and fixation using two $1.7 \mathrm{~mm}$ titanium miniscrews. The patients treatments had no complications and all metatarsal bones healed in six weeks with a significantly reduction of intermetatarsal $\mathrm{IV}^{\text {th }} / \mathrm{V}^{\text {th }}$ angle, from 10.3 to 6.8 degree. The authors concluded that Scarf Osteotomy is a safe and adeguate procedure in symptomatic TB.

The second article on the Scarf Osteotomy [26] evaluates a cohort of symptomatic patients in whom TB is treated using the same technique of the first study [25] and applying two $2.0 \mathrm{~mm}$ AO screws. This study reports the middle and long terminal results (i.e. mean follow-up period of six years and six months) of the treatment of 28 patients. Their satisfaction and clinical evaluation, according to the AOFAS (forefoot) scoring system, are performed. The results are: $86 \%$ completely satisfied, $11.4 \%$ satisfied with reservations and $3 \%$ dissatisfied; $91 \%$ considered themselves better than before surgery, while $8.6 \%$ felt they were no better; $91 \%$ of patients said they would undergo surgery under the same conditions again. The AOFAS scoring recovery is from a 44.1 to 91.8 at six month follow-up, that final one was 88.1; then, no complications are recorded. Also in this study, Scarf Osteotomy results as the technique that ensures good results for TB in a middle and long time follow-up.

The third article is a recent study of three welsh surgeons that have purposed Scarf Osteotomy for 12 cases affected by TB. The Scarf Osteotomy is called Reverse by the authors because it is compared to the traditional technique for the first metatarsal bone. After surgical correction of the $I V^{\text {th }} / \mathrm{V}^{\text {th }}$ metatarsal angle, no corrections to the metatarso-phalageal angle and no rotation of the head fragment have been done. Finally, they fixed Vth metatarsus bone by one or two 2.5 $\mathrm{mm}$ screws inserted in a dorso-plantar direction. All twelve patients are evaluated with a mean follow-up of twelve months, with radiological and clinical evaluation, according to the same AOFAS (forefoot) scoring system. No complications are recorded, and the surgical treatment has had the following results: a reduction from $13.1^{\circ}$ to $7.27^{\circ}$ of intermetatarsal angle, from $19.9^{\circ}$ to $6.36^{\circ}$ of metatarso-phalangeal angle, and an improvement of their clinical condition from 54.25 to 89.58 .

In all three studies the surgical treatment has been performed for a painful prominence of the fifth metatarsal and an increased IV ${ }^{\text {th }} / \mathrm{V}^{\text {th }}$ intermetatarsal angle. In the first clinical trial the mean patient's age is very low and gender is not specified: thus, this article is less comparable to the other two studies. The second study has evaluated middle and long term results: a rating scale improvement has been shown 6 months after surgery (91.8pt); later, 5 years after, it was reduced $(88.1 \mathrm{pt})$. Despite this slight decrease, this article shows that Scarf Osteotomy is also stable over time. The third article shows the type of performed osteotomy that refers to the traditional technique reported to the big toe. This type of osteotomy is defined as reverse, even if it is the same of that of the other two studies. Also in this third study, the findings are positive.

In conclusion, although in these years many surgical techniques

Table 1. Articles that explane in the title the keywords Scarf Osteotomy and Tailor's Bunion.

\begin{tabular}{|c|c|c|c|c|c|}
\hline Clinical Study & $\begin{array}{l}\text { Study design/target } \\
\text { population }\end{array}$ & Outcome measures & Evaluating scale & Mean follow-up & Results \\
\hline \multirow[t]{2}{*}{$\begin{array}{l}\text { Seide and Petersen } \\
\text { [25] }\end{array}$} & \multirow[t]{2}{*}{$\begin{array}{l}\text { Clinical trial: } \mathrm{n} 10 \\
\text { (mean of age } 26.1 \text { ) }\end{array}$} & Recovery of pain & $\begin{array}{l}\text { Forefoot Scoring System [12], } \\
\text { residual pain, self-assessment } \\
\text { of the cosmetic result (in four } \\
\text { categories) }\end{array}$ & \multirow[t]{2}{*}{14 months } & $\begin{array}{l}\text { Ffss recovery from } 29.5 \mathrm{pt} \text { to } 73 \mathrm{pt} \text {, no patients with } \\
\text { residual pain, } 8 \text { patients with excellent cosmetic } \\
\text { self-assessment and two with good cosmetic self- } \\
\text { assessment }\end{array}$ \\
\hline & & $\begin{array}{l}\text { Reduce radiographically of } \mathrm{IV}^{\text {th }} \mathrm{V}^{\text {th }} \\
\text { intermetatarsal angle }\end{array}$ & $\begin{array}{l}\text { Weight-bearing dorsoplantar } \\
\text { radiographs }\end{array}$ & & $\begin{array}{l}\text { IVth Vth intermetatarsal angle value was been } \\
\text { reducted from } 10.3^{\circ} \text { to } 6.8^{\circ} \text {. }\end{array}$ \\
\hline \multirow[t]{2}{*}{$\begin{array}{l}\text { Maher and Kilmatin } \\
{[26]}\end{array}$} & \multirow[t]{2}{*}{$\begin{array}{l}\text { Clinical trial: } \mathrm{n} 28(9 \\
\text { males and } 19 \text { female, } \\
\text { mean of age } 46)\end{array}$} & Recovery of pain & $\begin{array}{l}\text { AOFAS (forefoot) score and } \\
\text { patient satisfaction }\end{array}$ & \multirow[t]{2}{*}{6.5 years } & $\begin{array}{l}\text { AOFAS scoore recovery from } 44.1 \mathrm{pt} \text { to } 88.1 \mathrm{pt} \text {. } \\
86 \% \text { satisfied, } 11.4 \% \text { satisfied with reservation and } \\
3 \% \text { dissatisfied. } 91 \% \\
\text { considered themselves better than before surgery, } \\
8.6 \% \text { felt they were no better. }\end{array}$ \\
\hline & & $\begin{array}{l}\text { Reduce radiographically of } \mathrm{IV}^{\text {th }} \mathrm{V}^{\text {th }} \\
\text { intermetatarsal angle }\end{array}$ & $\begin{array}{l}\text { Weight-bearing dorsoplantar } \\
\text { radiographs }\end{array}$ & & $\begin{array}{l}\text { IVth Vth intermetatarsal angle value was been } \\
\text { reducted from } 9.9^{\circ} \text { to } 5.7^{\circ} \text {. }\end{array}$ \\
\hline \multirow[t]{2}{*}{ Guha et al. [27] } & \multirow{2}{*}{$\begin{array}{l}\text { Clinical trial: } \mathrm{n} 12(10 \\
\text { female and } 2 \text { males, } \\
\text { mean of age } 57)\end{array}$} & Recovery of pain & AOFAS (forefoot) score & \multirow[t]{2}{*}{12 months } & AOFAS scoore recovery from $54.2 \mathrm{pt}$ to $89.6 \mathrm{pt}$. \\
\hline & & $\begin{array}{l}\text { Reduce of IVth Vth intermetatarsal } \\
\text { angle and metatarso-phalageal angle } \\
\text { radiographically }\end{array}$ & $\begin{array}{l}\text { Weight-bearing dorsoplantar } \\
\text { radiographs }\end{array}$ & & $\begin{array}{l}\text { IVth Vth intermetatarsal angle value reducted from } \\
13.1^{\circ} \text { to } 7.3^{\circ} \text {. Metatarso-phalageal angle reducted } \\
\text { from } 19.9^{\circ} \text { to } 6.36^{\circ} \text {. }\end{array}$ \\
\hline
\end{tabular}


are developed, the Scarf Osteotomy is the most reliable procedure in $\mathrm{TB}$ in according with the literature. In particular, the main advantages are: a quick mobilization of the patient and, few related complications after the surgery. It also helps to correct the intermetatarsal angle, while maintaining an excellent sagittal and transverse plane stability.

\section{References}

1. Davies H (1949) Metatarsus quintus valgus. Br Med $J$ 1: 664. [Crossref]

2. Koti M, Maffulli N (2001) Bunionette. J Bone Joint Surg Am 83-83A: 1076-1082. [Crossref]

3. Radl R, Leithner A, Koehler W, Scheipl S, Windhager R (2005) The modified distal horizontal metatarsal osteotomy for correction of bunionette deformity. Foot Ankle Int 26: 454-457. [Crossref]

4. Vienne P, Oesselmann M, Espinosa N, Aschwanden R, Zingg P (2006) Modified Coughlin procedure for surgical treatment of symptomatic tailor's bunion: a prospective followup study of 33 consecutive operations. Foot Ankle Int 27: 573-580. [Crossref]

5. Legenstein R, Bonomo J, Huber W, Boesch P (2007) Correction of tailor's bunion with the Boesch technique: a retrospective study. Foot Ankle Int 28: 799-803. [Crossref]

6. Giannini S, Faldini C, Vannini F, Digennaro V, Bevoni R, et al. (2008) The minimally invasive osteotomy "S.E.R.I." (simple, effective, rapid, inexpensive) for correction of bunionette deformity. Foot Ankle Int 29: 282-286. [Crossref]

7. Mann RA, Coughlin MJ (1998) Keratotic disorders of the plantar skin. In: Surgery of the Foot and Ankle. Mann RA, Coughlin MJ. St Louis, Mosby: 415-423.

8. Addante JB, Chin M, Makower BL, Lescosky FA, Nowick AR (1986) Surgical correction of tailor's bunion with resection of fifth metatarsal head and silastic sphere implant: an 8-year follow-up study. J Foot Surg 25: 315-320. [Crossref]

9. Fuss HG, Munich B (1951): 145.

10. Leach RE, Igou R (1974) Metatarsal osteotomy for bunionette deformity. Clin Orthop Relat Res: 171-175. [Crossref]

11. Sponsel KH (1976) Bunionette correction by metatarsal osteotomy: preliminary report. Orthop Clin North Am 7: 809-819. [Crossref]

12. Kitaoka HB, Leventen EO (1989) Medial displacement metatarsal osteotomy for treatment of painful bunionette. Clin Orthop Relat Res: 172-179. [Crossref]
13. Throckmorton JK, Brandlee N (1974) Trasverse V-sliding osteotomy: a new surgical procedure for correction of tailor's bunion deformity. J Foot Surg 18: 117.

14. Kitaoka HB, Patzer GL (1998) Chevron osteotomy of lesser metatarsals for intractable plantar callosities. J Bone Joint Surg Br 80: 516-518. [Crossref]

15. Mercado OA (1979) Ann Atlas of Foot Surgery. Carolando Press, Oak Park, Illinois 1: 165 .

16. Haber JH, Kraft J (1980) Crescentic osteotomy for fifth metatarsal head lesions. J Foot Surg 19: 66-67. [Crossref]

17. Buchbinder IJ (1982) DRATO procedure for tailor's bunion. J Foot Surg 21: 177-180 [Crossref]

18. Yu GV, Ruch JA, Smith TF (1987) Comprehensive Textbook of Foot Surgery. ED Mc Glamry. Williams and Wilkins, Baltimore.

19. Mc Kreever DC (1959) Excision of the fifth metatarsal head. Clin Orthop 13: 321.

20. Coughlin MJ (1993) Treatment of bunionette deformity. Myerson M edn. Current treatment in foot and ankle. Mosby, St Louis.

21. Lelievre J (1956) Exostosis of the head of the fifth metatarsal bone; tailor's bunion Concours Med 78: 4815-4816. [Crossref]

22. Du Vriev HL (1965) Surgery of the Foot. ( $2^{\text {nd }}$ edn). Mosby, St Luis.

23. Barouk LS (1992) Chirurgie de l'HV. Interet de l'osteotomie de varisation - de rotation phalangienne. Actual Med Chir Pied 8: 102.

24. Barouk LS (1992) Notre experience de l'osteotomie Scarf des premier e cinquiene metatarsien. Actul Med chir Pied 8: 67.

25. Seide HW, Petersen W (2001) Tailor's bunion: results of a scarf osteotomy for the correction of an increased intermetatarsal IV/V angle. A report on ten cases with a 1-year follow-up. Arch Orthop Trauma Surg 121: 166-169. [Crossref]

26. Maher AJ, Kilmartin TE (2010) Scarf osteotomy for correction of Tailor's bunion: midto long-term followup. Foot Ankle Int 31: 676-682. [Crossref]

27. Guha AR, Mukhopadhyay S, Thomas RH (2012) 'Reverse' scarf osteotomy for bunionette correction: Initial results of a new surgical technique. Foot Ankle Surg 18: 50-54. [Crossref]

28. Barouk LS (1994) L'osteotomie cervico-capitale de Weil dans les metatarsalgies medianes. Med Chir Pied 10: 1.

29. Schwartz N, Groves ER (1987) Long-term follow-up of internal threaded Kirschnerwire fixation of the scarf bunionectomy. J Foot Surg 26: 313-316. [Crossref]

Copyright: $\odot 2015$ Caforio M. This is an open-access article distributed under the terms of the Creative Commons Attribution License, which permits unrestricted use, distribution, and reproduction in any medium, provided the original author and source are credited. 